\title{
When does corporate governance matter? Evidence from across the corporate life-cycle
}

\author{
Thomas O'Connor \\ Department of Economics, Finance and Accounting, \\ NUI Maynooth, Co. Kildare, Ireland, and \\ Julie Byrne \\ Smurfit Graduate Business School, University College Dublin, Dublin, Ireland
}

\begin{abstract}
Purpose - The purpose of this paper is to explore the relationship between corporate governance and firm value at different stages of the corporate life-cycle.

Design/methodology/approach - The authors use two measures, commonly employed in the literature, to differentiate between "immature" and "mature" firms, and estimate separate governance-value regressions for each set of firms.

Findings - The findings suggest that it is differences in the resource/strategic governance functions, which manifest in young firms which result in differences in value across firms, all else equal. The authors find no relationship between governance and firm value for older firms. Hence, differences in the monitoring aspect of governance between mature firms are not rewarded with a value premium. Research limitations/implications - The findings imply that the strategic and resource roles of governance are "must haves" for firms since firms that score highly on these fronts are valued more highly. In contrast, differences in the monitoring aspect of governance are not rewarded, suggesting that effective monitoring is not a necessity, but rather a "nice to have". The analysis is limited to a small sample of emerging market firms, and it would be of interest to extend this analysis to a larger and broader sample of firms.

Originality/value - The findings suggest that corporate governance is not valued at all stages of the corporate life-cycle.
\end{abstract}

Keywords Corporate governance, Firm value, Emerging markets, Corporate life-cycle

Paper type Research paper

\section{Introduction}

A central issue in empirical corporate governance studies concerns the relationship between corporate governance and firm value. The collective literature to date points to a positive causal relationship between corporate governance and firm value (see Bebchuk et al., 2009; Black et al., 2012, 2015). Better-governed firms are valued more highly than poorly governed firms, and (voluntary) governance improvements tend to cause (positive) changes in value (see Black et al., 2015; Morey et al., 2009; Chhaochharia and Laeven, 2009)[1]. Closely related to these governance-value studies are governance-prediction studies (see Klapper and Love, 2004; Durnev and Kim, 2005; Black et al., 2006a; Doidge et al., 2007 to name but a few). These studies seek to identify the firm, industry, and country-level factors, which at a particular point in time, explain differences in corporate governance quality between firms. Braga-Alves and Morey (2012) provide an exception. They examine how a change in firm/institutional characteristics predicts changes in governance.

In the most recent governance-prediction literature, the emphasis has shifted towards an examination of the dynamic nature of the principal-agent relationship by exploring

Received 1 November 2013

Revised 16 June 2014

3 September 2014

9 October 2014

Accepted 9 October 2014 
MF

41,7

674

how corporate governance quality changes within-firms over the corporate life-cycle (see Filatotchev et al., 2006; O'Connor and Byrne, 2015). While neither study can draw on longitudinal governance data in order to track governance changes within-firms, their analysis suggests that firms voluntarily alter their governance practices over their lifetime. Filatotchev et al. (2006) point to the fact that the corporate governance function is multi-faceted, and serves a strategic, resource, and control/monitoring roles in firms, and since these functions are required by firms at different life-cycle stages, governance changes along the firm life-cycle (see also McCahery and Vermuelen, 2014). O'Connor and Byrne (2015) build on the work of Filatotchev et al. (2006). They augment a standard governance-prediction model with proxies for a firm's life-cycle and show that corporate governance quality is not static, but actually improves along the corporate life-cycle[2]. Their work suggests that "mature" firms are better governed overall than their "immature" counterparts[3].

While the relationship between corporate governance and firm value has attracted much attention, what has attracted little or no attention is when the "governance premium" manifests. This is surprising since theory says that it is the strategic/ resource roles of governance which create value for firms, while it is the role of the control/monitoring function to preserve this value (see Filatotchev et al., 2006). In this paper, we examine how the relationship between corporate governance and firm value differs along the corporate life-cycle for a sample of emerging market firms. We do so because, while there is evidence which suggests that governance is valuable at different life-cycle stages, it is not so obvious in which life-cycle stage governance is the most valuable. On the one hand, a traditional and narrow-view of governance would suggest that the "governance premium" is attributable to differences in the monitoring function of governance alone across firms. Jensen's $(1986,1993)$ free-cash flow hypothesis suggests that the real value of corporate governance to the firm lies in the monitoring and control functions that governance provides (see Filatotchev et al., 2006). The central premise of Jensen's $(1986,1993)$ argument is that corporate governance is designed to address "agency problems" between shareholders and managers (i.e. the principal-agent perspective) or minority and majority (controlling) shareholders (i.e. the principal-principal perspective), and since agency conflicts are most severe when firms are mature, then governance which serves to reduce the "agency costs of free cash flow" will be more highly valued when firms are mature[4]. However, this view is problematic on at least two fronts. First, the focus is too narrow and excludes the resource/strategic governance functions. The resource/strategic governance functions are of particular importance for young fast-growing firms, while the preservation of firm value created by the resource/strategic functions, achieved through effective monitoring, is more important for older more mature firms. Under the resource/strategic view, it is not necessarily the independence of the board that matters, but rather its composition. For example, young firms benefit from appointing external directors to the board with considerable business and finance expertise (see Filatotchev et al., 2006). Second, companies like Apple and Walmart continue to flourish, while at the same time the independence of the board of directors at both firms has been the subject of much criticism (see Kane and Lubin, 2010; Satariano, 2014). The fact that Apple (and some other firms) continues to attract the support of shareholders, while at the same time adopting an atypical corporate governance monitoring function potentially has some important implications for the relationship between corporate governance practices and firm value. The most obvious implication, and the one most relevant for the purposes of this paper is that not all governance functions matter for firm value, and some, say board independence for example, may be perceived more as a "nice-to-have" rather than a 
"must-have"[5]. However, at the same time there is ample evidence to suggest that a "governance premium" exists, which suggests that some aspects of governance are "must-haves". Therefore, by examining the relationship between corporate governance and firm value for mature and immature firms alike, we can gain an insight into how important the resource and strategic vis-à-vis the monitoring functions are for firm value.

Hence, in this paper, we seek to separate the "nice to haves" from the "must haves" by examining how the relationship between corporate governance and firm value differs along the corporate life-cycle for a sample of emerging market firms. To do so, we perform a governance-value study using two years of Credit Lyonnais Securities Asia (CLSA) corporate governance data for a sample of 225 emerging market firms. We focus on the emerging market firms covered by CLSA for two reasons. First, we require a governance measure whose coverage is broad enough to capture the strategic, resource and monitoring roles of governance. CLSA governance data does just that as it covers broad aspects of governance (e.g. transparency, independence, accountability). Much work which examines corporate governance for US firms employ either the G-Index of Gompers et al. (2003) or the E-Index of Bebchuk et al. (2009), neither of which would be suitable for the purpose of this paper because in both cases each governance measure is too narrow in its focus. Second and also using CLSA data, O'Connor and Byrne (2015) establish that different governance functions are prominent at different life-cycle stages. The governance functions which perform a strategic and resource role are prominent in younger firms, while aspects of governance which monitor managerial behaviour are largely evident in older more mature firms. We extend the work of O'Connor and Byrne (2015) and examine whether it is the monitoring or resource/strategic or perhaps even both functions of governance which matter for firm value. Our findings suggest that it is the resource/strategic governance functions that are rewarded, but not the monitoring function. The resource/strategic functions of governance appear to be "must-haves" since they are rewarded, while the monitoring function does not appear to be a necessity but a "nice to have".

The paper proceeds as follows. The next section describes the data. Section 3 discusses our main findings, while Section 4 concludes.

\section{Data}

We use the corporate governance scores developed by CLSA (see Gill, 2001, 2002)[6]. The CLSA governance ratings range from a low of 0 to a high of 100 with higher values suggesting better quality corporate governance. The ratings are calculated for each of the firms in 2001 and 2002. The rating for each individual firm, for which there is 495 in total across 25 countries, is a composite measure of 57 qualitative, binary questions which span seven distinct governance categories, namely management discipline, transparency, independence, accountability, responsibility, fairness, and social awareness. The first six governance provisions have a 15 per cent weighting in the overall index, while social awareness has a 10 per cent weighting.

We use Tobin's $q$ to proxy for firm value (Klapper and Love, 2004; Chi, 2005; Black et al., 2006, 2012, 2015) all use Tobin's $q$ to proxy for firm value in governance-value studies; Doidge et al. (2004, 2009) do so in cross-listing studies; and Mitton and O'Connor, 2012 in a stock market liberalization study). Tobin's $q$ is defined as the book value of debt plus market capitalization divided by the book value of assets[7]. We control for a number of determinants of firm value (and corporate governance). These include firm size, growth, profitability, leverage, asset tangibility, and whether the firm is cross-listed in the USA or not in 2001 and 2002. All firm-level variables are 
$\mathrm{MF}$

41,7

676

sourced from Worldscope and a description of how each is measured is presented in Appendix 1. Appendix 1 also reports some summary statistics for each variable. All information on US cross-listings is sourced from the Bank of New York-Mellon (www.adrbnymellon.com), and cross-referenced with data from Citibank (wwss.citissb. com/adr) and JP Morgan (www.adr.com), the New York Stock Exchange (www.nyse. com), and the NASDAQ (www.nasdaq.com) to ensure that we classify firms according to their correct cross-listing status as of 2001 and 2002. We group all cross-listing firms together, rather than differentiate by cross-listing type (i.e. Level 1, Level 2, Level 3, and Rule 144a American Depositary Receipts (ADR)). In all, 75 out of our total number of 225 firms are cross-listed in the USA in 2001 and 2002[8].

The final sample is presented in Table I. There are 225 firms in total across 18 countries, namely Argentina, Brazil, Chile, China, Colombia, Hong Kong, Hungary, India, Indonesia, Korea, Malaysia, Mexico, Philippines, Singapore, South Africa, Taiwan, Thailand, and Turkey. The number of sample firms provided by each country varies greatly with India (41), Taiwan (26), and Hong Kong (26) providing the greatest numbers, while Argentina, Colombia, and Hungary, provide just one firm each. Each firm is available in both sample years which results in a final sample with 450 firm-year observations. Columns 3 through 6 present the median and standard deviation corporate governance in 2001 and 2002. They reveal a number of important features of corporate governance quality already documented in the literature to date. First, there exists sizeable differences in corporate governance quality across and within-countries (see also Klapper and Love, 2004). The CLSA data says that firms are best-governed in South Africa (the average of 2001 and 2002 median governance is 78.60) and Singapore (66.18), and poorly governed in Indonesia (36.60). The large standard deviations say that not all firms in China are poorly governed, while not all firms in South Africa are as well-governed as the median firm. Second, between 2001 and 2002, the governance practices of the median firm increased, in among others, Korea (change is 12.10), India (5.50), Taiwan (5.65), and Thailand (3.80). In contrast, governance quality has fallen in Argentina (14.10), Brazil (13.70), and Colombia (6.50)[9].

The remaining columns of Table I present summary measures for Tobin's $q$ and our two corporate life-cycle variables, namely, the ratio of retained equity to total assets and dividend payout. Dividend payout is measured as dividends to assets. The median firm is most highly valued in India (Tobin's $q$ is 2.03), Turkey (1.91) and Taiwan (1.65). The sole firms in Argentina (0.99) and Colombia (0.93) are lowly valued. Mature firms are evident in South Africa (both ratio of retained equity to total assets and dividend payout are high).

\section{Results and discussion}

We begin by examining the relationship between firm value and corporate governance by estimating pooled ordinary least squares, firm fixed effects, and random effects regressions. We use firm and random effects to account for the unobserved heterogeneity that pooled ordinary least squares regressions do not account for. We report coefficient estimates from random effects regressions because of concerns that our governance variable changes little within-firms between 2001 and 2002. The primary shortcoming of using random effects is that the random effects specification assumes that the unobserved heterogeneity is uncorrelated with all right-hand side variables. In the firm-fixed and random effects regressions, we find that White (1980) and clustered (by firm) standard errors are broadly similar, and our main conclusions remain qualitatively the same assuming White (1980) and clustered (by firm) standard errors. This is not surprising since our panel is short, and thus the firm effect is less likely to decay and 


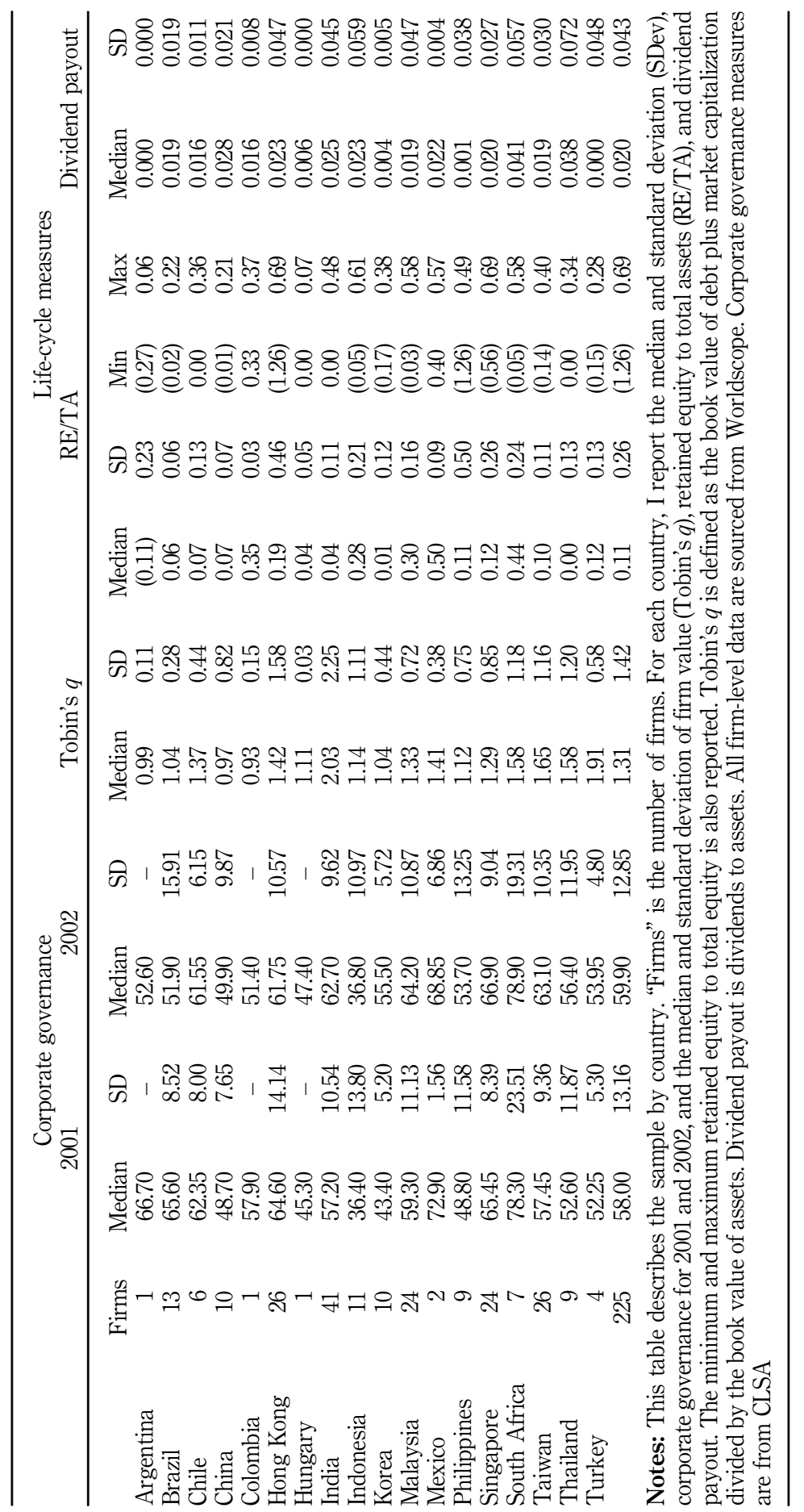

Corporate governance

677

Table I. Sample description 
MF

41,7

678

remain (almost) fixed, and is thus largely captured using the firm fixed (and random) effects (see Petersen, 2009 for a discussion). In the pooled ordinary least squares regressions, the standard errors are clustered by firm. In all regressions we include a time (year) dummy for 2002[10].

We use an extensive set of control variables commonly used in the literature, namely, firm size, growth opportunities, the ratio of EBIT/Assets, the ratio of net income/assets, leverage, the ratio of PPE/Sales, and whether a firm is cross-listed on the USA or not. Our 75 cross-listed firms are cross-listed in both 2001 and 2002. Consequently, the cross-listing variable is excluded from the fixed-effects regressions because it has no within-firm variation.

The results from the pooled, random, and fixed-effects regressions are presented in Table II. They suggest a positive relationship between firm value and corporate governance. The coefficient estimates for corporate governance are positive and significant in all but one regression. The coefficient estimates range from 0.004 to 0.027 , depending on the specification used, implying than an improvement in corporate governance leads to an increase in firm value. With respect to the control variables, and like Black et al. (2015), we find that both the ratio of net income/total assets and leverage are positively and significantly related to firm value. The ratio of net income/assets is an indicator of profitability and a higher value implies a higher efficiency in utilizing a firm's asset base. The positive relationship observed between leverage and firm value is unsurprising because leverage provides tax shields and serves to reduce the free-cash flow problem, thus enhancing firm value. We find a negative

\begin{tabular}{lccc}
\hline & POLS & Fixed effects & Random effects \\
\hline Corporate governance & $0.027(3.59)^{* * * *}$ & $0.004(0.80)$ & $0.013(2.56)^{* * * *}$ \\
Size & $-0.183(1.15)$ & $-2.277(3.41)^{* * *}$ & $-0.325(1.85)^{*}$ \\
Growth & $-0.428(1.81)^{*}$ & $0.017(0.11)$ & $-0.387(2.52)^{* *}$ \\
EBIT/assets & $0.726(0.40)$ & $-1.940(1.23)$ & $-0.466(0.31)$ \\
Net income/assets & $6.999(3.09)^{* * *}$ & $6.001(2.5)^{* *}$ & $5.829(2.79)^{* * *}$ \\
Leverage & $0.496(1.30)$ & $2.004(2.43)^{* *}$ & $0.736(1.73)^{*}$ \\
PPE/sales & $-0.037(0.73)$ & $-0.107(2.29)^{* *}$ & $-0.103(2.68)^{* * *}$ \\
US cross-listing & $0.050(0.33)$ & & $0.109(0.51)$ \\
Industry dummies & Included & Excluded & Included \\
Country dummies & Included & Excluded & Included \\
Time dummy & Included & Included & Included \\
No. observations & 450 & 450 & 450 \\
$R^{2}$ & 0.530 & 0.181 & 0.499
\end{tabular}

Notes: This table reports coefficient estimates from pooled ordinary least squares (POLS), firm fixed and random effects regressions, with robust $t$-statistics. The $t$-statistics are calculated using standard errors clustered by firm. The sample period is for the years 2001 and 2002. The dependent variable is Tobin's $q$. Tobin's $q$ is calculated as the book value of debt plus market capitalization divided by the book value of assets. Corporate governance measures are from CLSA, and are calculated as an equally weighted average of discipline, transparency, independence, accountability, responsibility, fairness, and social responsibility. All other variables are defined in the main text. All firm-level data is sourced from Worldscope and information on firms cross-listing in the USA from Bank of New York-Mellon (www.adrbnymellon.com), and cross-referenced with data from Citibank (wwss.citissb.com/adr) and JP Morgan (www.adr.com), the New York Stock Exchange (www.nyse.com), and the NASDAQ (www. Table II. nasdaq.com). A full set of industry, country, and time dummies are included where indicated but not Regression estimates reported. ***,***Significant at the 10,5 , and 1 per cent levels, respectively 
(sometimes significant) relationship between firm size and firm value, capturing the small firm effect. The relationship between growth and firm value and EBIT/Assets and firm value is ambiguous, while the effect of cross-listing in the USA on firm value is positive but insignificant[11]. Finally, like Lehn et al. (2009), but not Black et al. (2012), we find that PPE/Sales is negatively related to firm value.

Next, we attempt to identify at what stage of the corporate life-cycle is governance most important for firm value. We begin by dividing our sample into immature and mature firms, respectively. We use two measures to proxy for the maturity of a firm. First we use corporate dividend payout; the assumption being that mature firms pay larger dividends (see DeAngelo et al., 2006; Bulan and Subramanian, 2009)[12]. Previous evidence suggests that firms that are at the growth stage of their life-cycle tend to have lower dividend ratios (see Anthony and Ramesh, 1992). Shareholders will consent to lower dividends from less mature firms that have greater growth opportunities because by investing in these profitable growth opportunities, firms will increase the value of the firm, thus increasing shareholder wealth. Conversely, at the mature stage of their life-cycle, as growth opportunities decrease, firms have less profitable investment opportunities and so, are more likely to initiate and continue to pay dividends[13].

The second measure we use to proxy for firm maturity is the ratio of retained equity to total assets, a measure that has been used extensively in the dividend literature (see DeAngelo et al., 2006; Denis and Osobov, 2008; Brockman and Unlu, 2011). DeAngelo et al. (2006), Denis and Osobov (2008), and Brockman and Unlu (2011) all show that dividend payout increases in the ratio of retained equity to total assets. As firms mature, the contribution of earned equity (relative to contributed equity) to total equity (and total assets) increases, since firms become more profitable and have a reduced investment opportunity set, reducing the need for external (contributed) capital, which ultimately results in free cash flow. Mature (immature) firms are characterized with high (low) ratios of dividend payout and retained equity to total assets, respectively[14].

In the first panel of Table III, mature firms (96 firms in total) are those whose ratio of retained equity to total assets is greater than the median ratio of retained equity to total assets. Immature firms (106 firms) are those whose ratio of retained equity to total assets is less than the sample median. In the second panel of Table III, and to account for differences in dividend payout across industries, mature firms (110 firms) are those whose dividend payout is greater than the median industry payout, while immature firms (115 firms) are those where dividend payout is less than the median industry payout[15].

We re-run our analysis with the sample separated into mature and immature firms and some interesting observations emerge. Coefficient estimates from firm fixed-effects (random effects) are outlined in the top (bottom) panels of Table III. The coefficient estimates on corporate governance for immature firms are higher than those on mature firms, and is statistically significant regardless of which measure is used to proxy for firm maturity. The coefficient estimates on corporate governance for mature firms are negative and insignificant in the firm fixed-effects regressions, and positive but statistically insignificant in the random effects regressions. In contrast, when we concentrate only on firms at early life-cycle stages, the coefficient estimates are positive and statistically significant in all four instances, ranging from 0.01 ( $t$ is $1.70 *)$ to 0.02 ( $t$ is $1.92 *)$. We interpret this finding in the following way. Corporate governance is more important to firms that are at the earlier phase of the corporate life-cycle[16]. 
Fixed effects

Corporate governance

680

Size
Growth

EBIT/assets

Net income/assets

Leverage

PPE/sales

US cross-listing

Industry dummies

Country dummies

Time dummy

No. Observations

$R^{2}$

Random effects

Corporate governance

Size

Growth

EBIT/assets

Net income/assets

Leverage

PPE/sales

US cross-listing

Industry dummies

Country dummies

Time dummy

No. Observations $R^{2}$

$$
\begin{gathered}
-0.011(1.71)^{*} \\
-3.081(2.22)^{* *} \\
0.423(1.50) \\
-3.886(2.67)^{* * * *} \\
11.098(3.68)^{* * *} \\
3.568(2.49)^{* *} \\
-0.150(0.92)
\end{gathered}
$$

Excluded
Excluded
Included
221
0.199

$0.006(0.76)$
$-0.487(2.39)^{* *}$
$-0.146(0.55)$
$-0.417(0.20)$
$9.206(2.69)^{* * *}$
$1.153(1.71)^{*}$
$-0.109(1.55)$
$0.091(0.34)$
Included
Included
Included
221
0.575

$0.020(1.92)^{*}$
$-2.660(4.55)^{* * *}$
$0.095(0.50)$
$-2.897(1.20)$
$6.684(2.11)^{* *}$
$1.500(1.38)$
$-0.067(1.28)$

Excluded

Excluded

Included

229

0.135

$0.018(1.99)^{* *}$
$-0.017(0.11)$
$-0.445(1.95)^{*}$
$-1.728(1.09)$
$5.704(3.30)^{* * *}$
$0.321(0.70)$
$-0.081(2.00)^{* *}$
$0.157(0.75)$
Included
Included
Included
229
0.508

$-0.005(0.74)$
$-2.546(1.59)$
$-0.362(1.05)$
$-4.136(1.51)$
$8.245(2.17)^{\text {** }}$
$0.979(0.62)$
$0.012(0.16)$

Excluded

Excluded

Included

192

0.158

$0.006(0.88)$
$-0.258(1.27)$
$-0.788(2.35)^{* * *}$
$-1.723(0.76)$
$8.181(2.19)^{* *}$
$-0.075(0.09)$

$-0.075(0.09)$
$-0.059(0.93)$

-0.245 (1.00)

Excluded

Excluded

Included

192

0.578
$0.010(1.70)^{*}$

-2.439 (3.71)***

0.443 (2.86)***

$-0.283(0.18)$

3.140 (1.38)

3.719 (3.34)****

$-0.234(2.48)^{* * *}$

Excluded
Excluded
Included
212
0.090

$0.015(2.11)^{* * *}$

-0.265 (1.19)

$-0.052(0.32)$

$0.652(0.41)$

2.088 (1.01)

0.967 (1.61)

$-0.154(1.97)^{\text {*** }}$

0.077 (0.29)

Excluded

Excluded

Included

212

0.423

Notes: This table reports coefficient estimates from firm fixed and random effects regressions, with $t$-statistics robust to firm-level clustering. The sample period is for the years 2001 and 2002. Separate regressions are estimated by level of retained equity to total asset and dividend payout, respectively. The dependent variable is Tobin's $q$. Tobin's $q$ is calculated as the book value of debt plus market capitalization divided by the book value of assets. Corporate governance measures are from CLSA, and are calculated as an equally weighted average of discipline, transparency, independence, accountability, responsibility, fairness, and social responsibility. All other variables are defined in the main text. All firm-level data are sourced from Worldscope and information on firms cross-listing in the USA from Bank of New York-Mellon (www.adrbnymellon.com), and cross-referenced with data from Citibank (wwss.citissb.

Table III.

Regression estimates by life-cycle stage com/adr) and JP Morgan (www.adr.com), the New York Stock Exchange (www.nyse.com), and the NASDAQ (www.nasdaq.com). A full set of industry, country, and time dummies are included where indicated but not reported. *******Significant at the 10,5 , and 1 per cent levels, respectively

Along the corporate life-cycle, firms will have different financing requirements. Firms with good growth opportunities are more likely to require external financing to pursue those opportunities and hence may find it optimal to improve corporate governance. Firms with access to profitable growth opportunities are typically younger firms at earlier stages of the life-cycle. Immature firms will need to mobilize capital and allocate this capital to profitable investment opportunities. In order to raise external finance at as low a cost as possible, the strategic and resource allocation roles of corporate 
governance are the most important (see Filatotchev et al., 2006). Establishing property rights and maintaining reliable and transparent accounts will be crucial to investors so it is of critical importance that corporate governance is focused on these functions. Furthermore, Francis et al. (2012) show that better governed emerging market firms can obtain bank loans from a wider variety of lenders at a lower rate of interest and with a longer maturity date.

Using a number of different life-cycle proxies, O'Connor and Byrne (2015) show that governance quality, and most notably, board independence is greatest for mature firms. The independence measure quantifies the extent to which the board of directors is independent from the controlling shareholder/manager, and thus better able to monitor their activities. Using a number of agency cost proxies, which arguably could be employed as life-cycle measures, Dey (2008) reaches similar conclusions in that certain monitoring functions of governance are greatest in firms with the most severe agency costs. Hence, at the latter stages of the corporate life-cycle, effective monitoring becomes a priority.

Previous studies have shown it is the monitoring role as opposed to the strategic and resource roles of governance that is most relevant for mature firms (see Filatotchev et al., 2006; O'Connor and Byrne, 2015). Our findings suggest that it is the strategic and resource functions of corporate governance, which is the most prominent role of governance in immature firms, which matters most for firm value. Differences in the strategic and resource roles of governance, which are dominant when firms are immature result in value differences between firms. It appears that, at the latter stages of the corporate life-cycle, better monitoring is not rewarded through higher firm value. These findings suggest that shareholders do not necessarily view effective monitoring as a "must-have" but rather a "nice to have" since differences in the monitoring function across firms do not result in differences in firm value, all else equal. In contrast, differences in the strategic/resource functions are rewarded with higher firm values, suggesting that these governance functions are "must haves". It would appear that firm growth, and the governance functions which promote growth are rewarded by shareholders (McCahery and Vermuelen, 2014).

In Table IV we explore whether the conclusions drawn from Table III are robust to a series of additional tests. In particular, we examine whether our findings are robust to: (1) alternative classification of mature and immature firms, (2) controlling for the agency substitution model of dividends, (3) the use of an alternative life-cycle measure, and finally (4), the use of an alternative measure of firm value, namely the market to book of assets. First, in relation to (1), we account for differences in dividend payout (and RE/TA) across countries and industries, and now classify firms as mature (immature) if their dividend payout (RE/TA) is greater (less) than the industry and country-adjusted sample median. Our findings remain qualitatively the same when we perform such an exercise (see columns labelled "industry and country adjusted dividend payout" and "industry and country adjusted RE/TA")[17]. Our second robustness test concerns the agency substitution model of dividends (see La Porta et al., 2000). The agency substitution model of dividends says that firms with abundant growth opportunities can substitute poor country-level investor protection with reputational capital by establishing a dividend payment history (see Gan et al., 2013). The implication is that young, growth firms pay large dividends. This finding has important implications for our paper since we designate high dividend-paying firms as mature, and as a consequence we may erroneously classify young high dividendpaying firms as mature and not immature as they undoubtedly are. To address this 
MF
41,7

682

Table IV.

Robustness tests

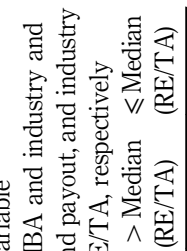

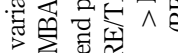

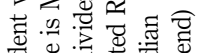

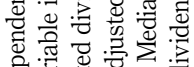

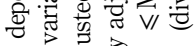

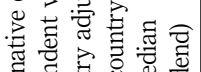

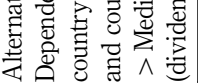

急

so

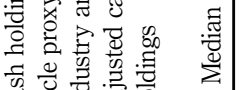

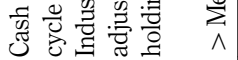

ت

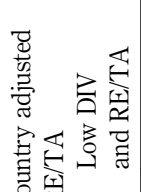

荘

跑要会

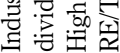

总管

实

焉

E

응

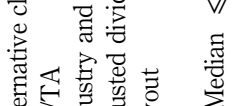

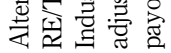

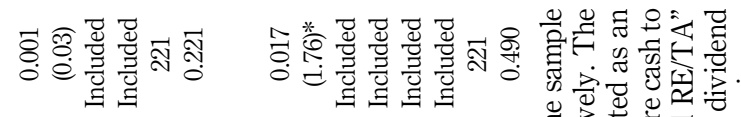

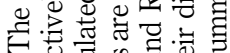

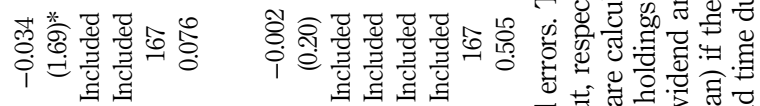

응 敢离

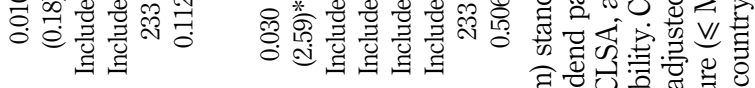

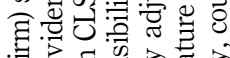

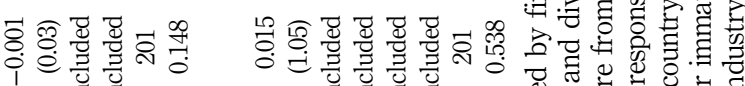

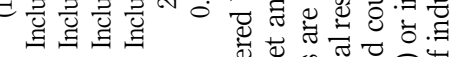

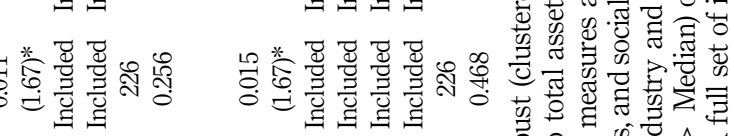

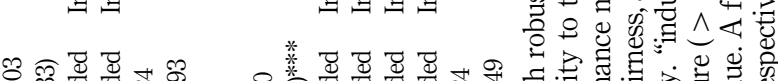

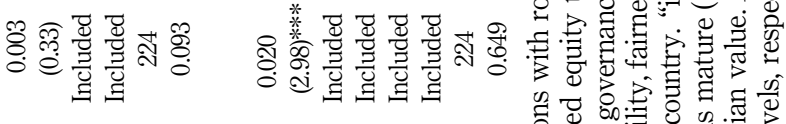

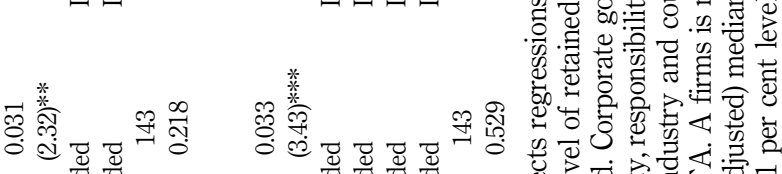

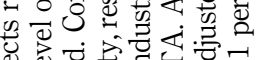

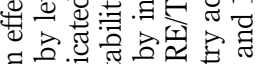

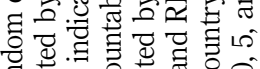

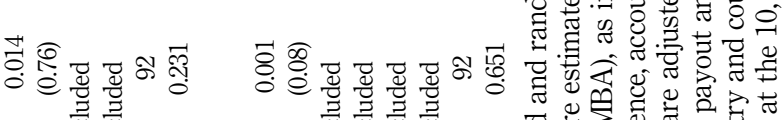

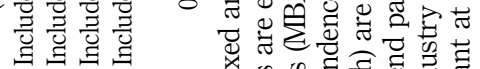

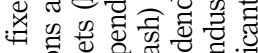

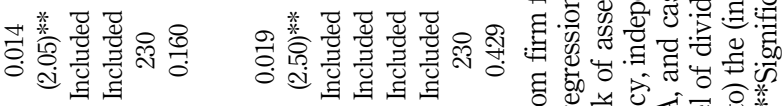

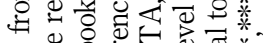

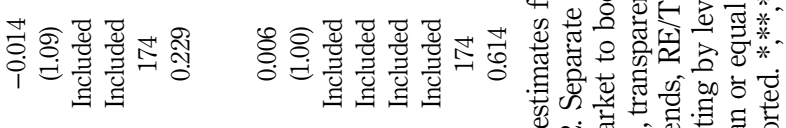

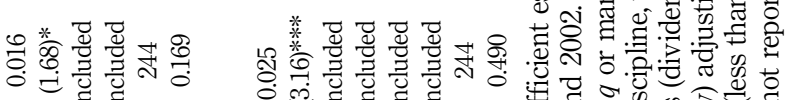

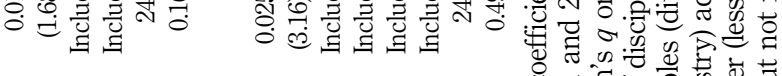

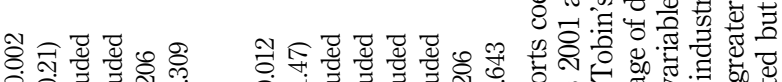

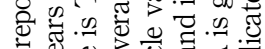

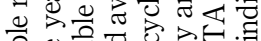

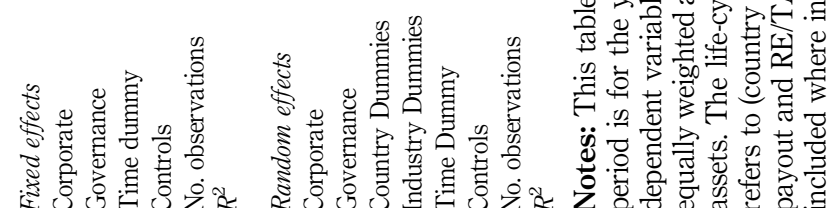

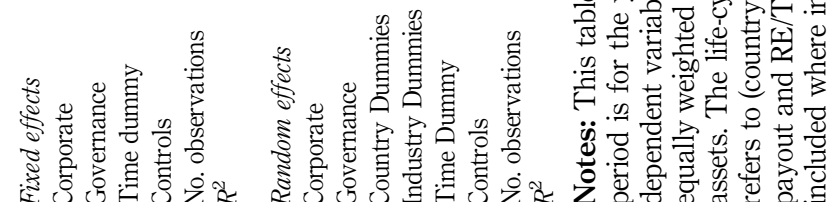

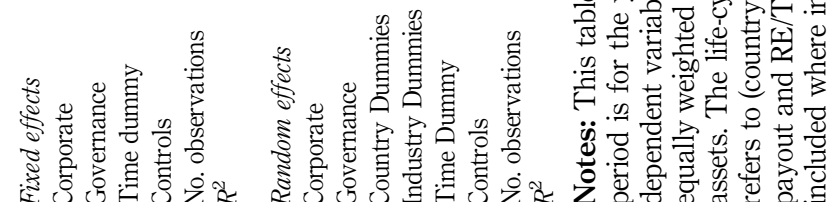


potential shortcoming, we classify mature (immature) firms as those with above (below)-median retained equity to total assets and dividend payout (see column labelled "industry and country adjusted dividend and RE/TA"). Young reputational building firms pay large dividends but are immature and thus have low (and potentially negative) retained equity to total assets. When we classify firms according to this criterion, we lose some firms as there are young firms (i.e. below-median RE/ TA) that pay large dividends, yet our conclusions remain the same as before. Third, we use cash holdings (cash to assets) as an alternative life-cycle proxy. Mature firms are those with above industry and country-adjusted cash holdings. Using cash holdings, our findings are not as conclusive as those reported in Table III and the early columns of Table IV, since in the random effects regressions; the coefficient estimates on the governance variable are positive, statistically significant, but not larger for mature firms[18]. Finally, in the remaining columns of Table IV, we use market to book of assets in place of Tobin's $q$. Our conclusions are generally the same when we use market to book of assets to measure firm value. Interestingly, in the firm fixed-effects regressions, governance is value destroying for mature firms. Black et al. (2012) show that in some countries (e.g. Brazil) individual governance functions (e.g. board structure) can destroy firm value.

\section{Conclusion}

The most recent work in governance-value studies suggest that, what are perceived to be "best" governance practices are not necessarily beneficial (value-enhancing) for all firms (see Black et al., 2015). What actually matters in corporate governance does not universally "fit-all", but is dependent on the culture and institutional setting in each individual country. Thus, firms tailor their governance needs to best suit the cultural and institutional setting that they find themselves domiciled in. For example, Griffin et al. (2013) show that using stock market based corporate governance scores, where traditionally there is a premium placed on the governance attributes of transparency, monitoring, and disclosure, firms in collectivist cultures score lowly, at least when compared to their counterparts in individualistic cultures. These findings do not necessarily say that firms in collectivist societies are poorly governed. Rather, they say that the governance attributes, which are valued in individualistic societies, are not so highly valued in collectivist societies, where close ties among corporate stakeholders render such governance functions less relevant.

Recent work also suggests that firms alter their governance needs across their life-cycle (see Filatotchev et al., 2006; O'Connor and Byrne, 2015). Governance attributes change and serves different functions as firms evolve. For example, for young, fast-growing firms, governance fulfils both a resource and strategic role, as firms strive to fund their expansion using external funds. For larger older firms, the monitoring role of governance is of primary importance, since these firms no longer require external capital. In this paper, we focus not on what matters in corporate governance, but instead endeavour to answer the question of when it matters. On theoretical grounds, and as already alluded to, there is ample evidence which suggests that governance potentially valuable for both "immature" and "mature" firms alike. However, the question of when governance matters the most is not so clear. Thus, we believe that the question of when governance matters the most remains an open empirical question.

We explore this issue here. We use corporate dividend payout and the ratio of retained equity to total assets to differentiate between "immature" and "mature" firms for a sample of 21 emerging market countries. In a series of governance-value 
MF

41,7

684

regressions, we find that governance matters, but only for immature firms. Differences in the strategic and resource roles of governance result in value differences between firms, whereas improvements in monitoring, prominent at the latter stages of the lifecycle are not similarly rewarded.

Given the nature of the governance data that we use, we are cognisant of the fact that our paper has limitations. Our sample of firms is limited to a small sample of emerging market firms, observed for just two years. It would be interesting to extend the sample coverage to a larger number of emerging and developed market firms, which could potentially be observed over an extended period of time. Our findings suggest that governance causes value, or more precisely, it is the strategic and resource functions of governance which creates value for firms. In this paper, there is no attempt to identify the exact strategic and resource functions which are so rewarding for young firms. We leave this question to future work. Our findings also suggest that more emphasis should be placed on examining the governance attributes of young firms rather than on older firms, where the focus has traditionally been placed.

\section{Notes}

1. Other studies include Klapper and Love (2004), Durnev and Kim (2005), Brown and Caylor (2006), Chi (2005), Black et al. (2006), and Black et al. (2012). See Love (2010) and Bozec and Bozec (2011) for reviews of this literature.

2. Others explore trends in (aggregate) corporate governance in calendar time (see De Nicola et al., 2008; Ananchotikul and Eichengreen, 2009). Both show that governance quality has improved over time. Sawicki (2009) documents improvements in corporate governance quality in post-Asian crisis Asia. Patel et al. (2002) analyse trends in corporate transparency and disclosure in emerging markets to the year 2000.

3. Others do include the age of the firm in governance-prediction models (e.g. Black et al., 2006). However, the age of the firm alone is unlikely to adequately capture differences in lifecycle stages within and between firms.

4. For a review of the "principal-principal" perspective in emerging markets, see Young et al. (2008).

5. The findings of Bebchuk et al. (2009) who show that not all of the provisions of the G-Index matter for firm value suggest that this is the case.

6. Others to use the CLSA data include Mitton (2004), Klapper and Love (2004), Durnev and Kim (2005), and Chen et al. (2009).

7. Market value of debt is proxied using its book value counterpart, and the replacement cost of assets is proxied using the book value of assets. Book value of debt is calculated as the book value of total assets less the book value of equity.

8. Since our sample of cross-listing firms is cross-listed in both years of our sample, the cross-listing variable has no within-firm variation, and as a result, is excluded from the (firm) fixed effects estimation.

9. De Nicola et al. (2008) and Ananchotikul and Eichengreen (2009) show that, with some exceptions, governance quality has improved over time.

10. We cluster by firm, but not at a higher-level e.g. country or industry, because where the number of clusters are small, the standard errors ( $t$-statistics) are biased downwards (upwards) (see Cameron et al., 2008 for a discussion). 
11. This finding is inconsistent with a large literature which shows that firms soon to cross-list in the USA are worth more than their non-cross-listing counterparts, and this "value premium" becomes larger once these firms cross-list (the "cross-listing premium") (see Doidge et al., 2004, 2009). The evidence with respect to whether a cross-listing in the UK results in a "cross-listing premium" is mixed. Bianconi and Tan (2009) find that a cross-listing on the main list of the London Stock Exchange results in a "cross-listing premium". Doidge et al., 2009 find no such premium. O'Connor (2009) and Nielsson (2013) document a "cross listing premium" for firms cross-listed on London's AIM. Again, Doidge et al. (2009) do not.

12. Bulan and Yan (2009) use a firm's dividend initiation history as a measure of corporate life-cycle.

13. Bulan et al. (2007) show that mature firms do not automatically initiate a dividend once they become mature, but tend to initiate a dividend in times when the dividend premium is high.

14. Dividend payout is available for all 225 firms but retained equity to total assets for only 202 firms in our final sample. Appendix 2 compares mature and immature firms. Mature firms are worth more (Tobin's q), are better governed, more profitable, have positive free cash flow and cash holdings. What is surprising is that in this sample of firms, immature firms are larger and have lower growth rates than do mature firms.

15. Firms are designated into one of 13 industries based on the following classifications using four-digit SIC codes: agriculture and food (0100-0999 \& 2000-2111); mining and construction (1000-1999, excluding 1300-1399); textiles and printing/publishing (2200-2799); chemicals (2800-2824, 2840-2899); pharmaceuticals (2830-2836); extractive (2900-2999, 1300-1399); durable manufacturers (3000-3999, excluding 3570-3579); transportation (4000-4899); utilities (4900-4999); retail (5000-5999); services (7000-8999, excluding 7370-7379); computers (7370-7379, 3570-3579, 3670-3679); public administration (9000+).

16. In a further set of tests, we confirm these findings. We perform a series of two-stage least squares regressions, in which we use the yearly industry country specific median values of governance to instrument for (firm level) corporate governance. This variable is included in the first stage, but not second-stage (reported in Appendix 3) regression. The idea is that industry/country specific governance is highly correlated with firm-level governance, but not correlated with firm value. The coefficient estimates are reported in Appendix 3. Again, they suggest that governance is only valuable at early life-cycle stages.

17. In unreported analysis, we find that our findings are qualitatively the same when we adjust retained equity to total assets by industry alone, and when we adjust both retained equity to total assets and dividend payout by country alone. These findings are available from the corresponding author upon request.

18. Using cash holdings as a life-cycle proxy is potentially problematic. The traditional view is that as firms mature their level of cash holdings increases. However, an alternative view is that corporate cash holdings decrease monotonically over the corporate life-cycle (see Dittmar and Duchin, 2011), because, amongst others, the firm's investment opportunity set diminishes, and presumably the need for cash diminishes too (see Ferreira and Vilela, 2004).

\section{References}

Ananchotikul, S. and Eichengreen, B. (2009), "Corporate governance reform in emerging markets”, Lournal of the Jabanese and International Economies, Vol. 23 No. 2, pp. 149-176.

Anthony, J. and Ramesh, K. (1992), "Association between accounting performance measures and stock prices: a test of the life-cycle hypothesis", Journal of Accounting and Economics, Vol. 15 Nos 2/3, pp. 203-227. 
MF

41,7

686

Bebchuk, L., Cohen, A. and Ferrell, A. (2009), "What matters in corporate governance”, Review of Financial Studies, Vol. 22 No. 2, pp. 783-827.

Bianconi, M. and Tan, L. (2009), "Cross listing premium in the US and UK destination", International Review of Economics and Finance, Vol. 19 No. 2, pp. 224-259.

Black, B., de Carvalho, A. and Gorga, E. (2012), "What matters and for which firms for corporate governance in emerging markets? Evidence from Brazil (and other BRIK countries)", Iournal of Corporate Finance, Vol. 18 No. 4, pp. 934-952.

Black, B., Jang, H. and Kim, W. (2006a), “Predicting firms' corporate governance choices: evidence from Korea”, Lournal of Corporate Finance, Vol. 12 No. 3, pp. 660-691.

Black, B., Love, I. and Rachinsky, A. (2006), "Corporate governance indices and firms' market values: time series evidence from Russia”, Emerging Markets Review, Vol. 7 No. 4, pp. 361-379.

Black, B., de Carvalho, A., Khanna, V., Kim, W. and Yurtoglu, B. (2015), "Methods of multi-country studies of corporate governance (and evidence from the BRIKT countries)", Journal of Econometrics, Vol. 183 No. 2, pp. 230-240.

Bozec, R. and Bozec, Y. (2011), "The use of governance indexes in the governance performance relationship literature: international evidence", Canadian Iournal of Administrative Sciences, Vol. 29 No. 1, pp. 79-98.

Braga-Alves, M. and Morey, M. (2012), "Predicting corporate governance in emerging markets", Journal of International Money and Finance, Vol. 31 No. 6, pp. 1414-1439.

Brockman, P. and Unlu, E. (2011), "Earned/contributed capital, dividend policy, and disclosure quality: an international study", Lournal of Banking and Finance, Vol. 35 No. 7, pp. 1610-1625.

Brown, L. and Caylor, M. (2006), “Corporate governance and firm valuation”, Lournal of Accounting and Public Policy, Vol. 25 No. 4, pp. 409-434.

Bulan, L. and Yan, Z. (2009), "The pecking order theory and the firm's life cycle”, Banking and Finance Letters, Vol. 1 No. 3, pp. 129-140.

Bulan, L. and Subramanian, N. (2009), "The firm life cycle theory of dividends", in Kent Baker, H. (Ed.), Dividends and Dividend Policy, Wiley, pp. 201-213.

Bulan, L., Subramanian, N. and Tanlu, L. (2007), “On the timing of dividend initiations”, Financial Management, Vol. 36 No. 4, pp. 31-65.

Cameron, C., Gelbach, J. and Miller, D. (2008), "Bootstrap-based improvements for inference with clustered errors", The Review of Economics and Statistics, Vol. 90 No. 3, pp. 414-427.

Chen, K., Chen, Z. and Wei, K. (2009), "Legal protection of investors, corporate governance, and the cost of equity capital”, Lournal of Corporate Finance, Vol. 15 No. 3, pp. 273-289.

Chhaochharia, V. and Laeven, L. (2009), "Corporate governance norms and practices", Lournal of Financial Intermediation, Vol. 18 No. 3, pp. 405-431.

Chi, J. (2005), "Understanding the endogeneity between firm value and shareholder rights", Financial Management, Vol. 34 No. 4, pp. 65-76.

DeAngelo, H., DeAngelo, L. and Stulz, R. (2006), "Dividend policy and the earned/contributed capital mix: a test of the life-cycle theory", Journal of Financial Economics, Vol. 81 No. 2, pp. 227-254.

De Nicola, G., Laeven, L. and Ueda, K. (2008), "Corporate governance quality: trends and real effects”, Journal of Financial Intermediation, Vol. 17 No. 2, pp. 198-228.

Denis, D. and Osobov, I. (2008), "Why do firms pay dividends? International evidence on the determinants of dividend policy”, Iournal of Financial Economics, Vol. 89 No. 1, pp. 62-82. 
Dey, A. (2008), “Corporate governance and agency conflicts”, Journal of Accounting Research, Vol. 46 No. 5, pp. 1143-1181.

Dittmar, A. and Duchin, R. (2011), “The dynamics of cash”, working paper, University of Michigan, Michigan.

Doidge, C., Karolyi, G. and Stulz, R. (2004), "Why are foreign firms listed in the US worth more?", Iournal of Financial Economics, Vol 71 No. 2, pp. 205-238.

Doidge, C., Karolyi, G. and Stulz, R. (2007), "Why do countries matter so much for corporate governance?", Lournal of Financial Economics, Vol. 86 No. 1, pp. 1-39.

Doidge, C., Karolyi, G. and Stulz, R. (2009), "Has New York become less competitive in global markets? Evaluating foreign listing choices over time", Iournal of Financial Economics, Vol. 91 No. 3, pp. 253-287.

Durnev, A. and Kim, E. (2005), "To steal or not to steal: firm attributes, legal environment, and valuation", Journal of Finance, Vol. 60 No. 3, pp. 1461-1493.

Ferreira, M. and Vilela, A. (2004), "Why do firms hold cash? Evidence from EMU countries", European Financial Management, Vol. 10 No. 2, pp. 295-319.

Filatotchev, I., Toms, S. and Wright, M. (2006), "The firm's strategic dynamics and corporate governance life-cycle”, International Iournal of Managerial Finance, Vol. 2 No. 4, pp. 256-279.

Francis, B., Hasan, I. and Song, L. (2012), “Are firm- and country-specific governance substitutes? Evidence from financial contracts in emerging markets?”, Journal of Financial Research, Vol. 35 No. 3, pp. 343-374.

Gan, J., Lemmon, M. and Wang, M. (2013), "Can firms build capital-market reputation to substitute for poor investor protection? Evidence from dividend policies", working paper, Hong Kong University of Science and Technology, Hong Kong.

Gill, A. (2001), “Saints and sinners: who's got religion?” Credit Lyonnais Securities Asia, Hong Kong.

Gill, A. (2002), "Make me holy [...] but not yet" Credit Lyonnais Securities Asia, Hong Kong.

Gompers, P., Ishii, J. and Metrick, A. (2003), "Corporate governance and equity prices", The Quarterly Journal of Economics, Vol. 118 No. 1, pp. 107-155.

Griffin, D., Guedhami, O., Kwok, C., Li, K. and Shao, L. (2013), "National culture, corporate governance systems and firm corporate governance practices", working paper, University of British Colombia, Vancouver.

Jensen, M.C. (1986), "Agency costs of free cash flow, corporate finance and take-overs”, American Economic Review, Vol. 76 No. 2, pp. 323-329.

Jensen, M.C. (1993), "The modern industrial revolution, exit and failure of internal control systems", Lournal of Finance, Vol. 48 No. 3, pp. 831-880.

Kane, Y. and Lubin, J. (2010), "On apple's board, fewer independent voices”, The Wall Street Journal, 24 March.

Klapper, L. and Love, I. (2004), "Corporate governance, investor protection and performance in emerging markets", Lournal of Corporate Finance, Vol. 10 No. 5, pp. 703-728.

La Porta, R., Lopez-de-Silanes, F., Shleifer, A. and Vishny, R. (2000), "Agency problems and dividend policy around the world”, Journal of Finance, Vol. 55 No. 1, pp. 1-33.

Lehn, K., Patro, S. and Zhao, M. (2009), "Determinants of the size and composition of US corporate boards: 1935-2000”, Financial Management, Vol. 38 No. 4, pp. 747-780.

Love, I. (2010), "Corporate governance and performance around the World: what we know and what we don't”, The World Bank Research Observer, Vol. 26 No. 1, pp. 42-70. 
MF

41,7

688

McCahery, J. and Vermuelen, E. (2014), "Six components of corporate governance that cannot be ignored”, Working Paper Nos 248/2014, European Corporate Governance Institute, Brussels.

Mitton, T. (2004), "Corporate governance and dividend policy in emerging markets", Emerging Markets Review, Vol. 5 No. 4, pp. 409-426.

Mitton, T. and O'Connor, T. (2012), "Investability and firm value", European Financial Management, Vol. 18 No. 5, pp. 731-761.

Morey, M., Gottesman, A., Baker, E. and Godridge, B. (2009), "Does better corporate governance result in higher valuations in emerging markets? Another examination using a new data set”, Journal of Banking and Finance, Vol. 33 No. 2, pp. 254-262.

O'Connor, T. (2009), "The valuation effects of cross-listing abroad for Irish firms", Irish Accounting Review, Vol. 16 No. 1, pp. 55-87.

O'Connor, T. and Byrne, J. (2015), “Governance and the corporate life-cycle”, International Iournal of Managerial Finance, Vol. 11 No. 1, pp. 23-43.

Patel, S., Balic, A. and Bwakira, L. (2002), "Measuring transparency and disclosure at firm-level in emerging markets”, Emerging Markets Review, Vol. 3 No. 4, pp. 325-337.

Petersen, M. (2009), "Estimating standard errors in finance panel data sets: comparing approaches", Review of Financial Studies, Vol. 22 No. 1, pp. 435-478.

Satariano, A. (2014), "Apple facing criticism about diversity changes bylaws", Bloomberg Technology, available at: www.bloomberg.com/news/articles/2014-01-06/apple-facing-criticism-aboutdiversity-changes-bylaws

Sawicki, J. (2009), "Corporate governance and dividend policy in Southeast Asia pre- and post-crisis", European Journal of Finance, Vol. 15 No. 2, pp. 211-230.

White, H. (1980), "A heteroscedasticity-consistent covariance matrix estimator and a direct test for heteroscedasticity", Econometrica, Vol. 48 No. 4, pp. 817-838.

Young, M., Peng, M., Ahlstrom, D., Bruton, G. and Jiang, Y. (2008), "Corporate governance in emerging economies: a review of the principal-principal perspective", Iournal of Management Studies, Vol. 45 No. 1, pp. 196-220.

\section{Further reading}

Nielsson, U. (2014), "Do less regulated markets attract lower quality firms? Evidence from the London AIM market”, Lournal of Financial Intermediation, Vol. 22 No. 3, pp. 335-352. 


\begin{tabular}{|c|c|c|c|c|c|c|c|c|}
\hline \multicolumn{2}{|c|}{ Variable description } & \multirow[b]{2}{*}{ Source } & \multicolumn{5}{|c|}{ Summary statistics } & \multirow[b]{3}{*}{689} \\
\hline Variable & Description & & Mean & Median & SD & Minimum & Maximum & \\
\hline Tobin's $q$ & $\begin{array}{l}\text { Tobin's } q \text { is defined as the } \\
\text { book value of debt plus } \\
\text { market capitalization } \\
\text { divided by the book value } \\
\text { of assets }\end{array}$ & Worldscope & 1.85 & 1.31 & 1.42 & 0.10 & 9.28 & \\
\hline $\begin{array}{l}\text { Market to } \\
\text { Book Ratio }\end{array}$ & $\begin{array}{l}\text { The ratio of the market to } \\
\text { book value of assets }\end{array}$ & Worldscope & 2.45 & 1.68 & 2.20 & 0.10 & 12.42 & \\
\hline $\begin{array}{l}\text { Corporate } \\
\text { Governance }\end{array}$ & $\begin{array}{l}\text { Equally weighted } \\
\text { composite measure of } \\
\text { management discipline, } \\
\text { transparency, } \\
\text { independence, } \\
\text { accountability, } \\
\text { responsibility, fairness and } \\
\text { social responsibility }\end{array}$ & $\begin{array}{l}\text { Gill (2001, } \\
\text { 2002) }\end{array}$ & 58.61 & 59.40 & 13.06 & 93.50 & 13.90 & \\
\hline $\begin{array}{l}\text { Retained } \\
\text { Equity }\end{array}$ & $\begin{array}{l}\text { Retained equity to total } \\
\text { assets }\end{array}$ & Worldscope & 0.14 & 0.11 & 0.26 & (1.26) & 0.69 & \\
\hline $\begin{array}{l}\text { Dividend } \\
\text { Payout }\end{array}$ & Dividends to total assets & Worldscope & 0.034 & 0.020 & 0.043 & 0.000 & 0.199 & \\
\hline $\begin{array}{l}\text { Capital } \\
\text { Intensity }\end{array}$ & $\begin{array}{l}\text { Property plant and } \\
\text { equipment to sales }\end{array}$ & Worldscope & 1.10 & 0.61 & 1.36 & 0.00 & 7.45 & \\
\hline Leverage & Debt to total assets & Worldscope & 0.47 & 0.47 & 0.19 & 0.04 & 0.80 & \\
\hline Size & Log of book assets in US\$ & Worldscope & 6.07 & 6.13 & 0.66 & 3.87 & 7.47 & \\
\hline Growth & $\begin{array}{l}\text { Logarithmic one-year asset } \\
\text { growth }\end{array}$ & Worldscope & 0.06 & 0.05 & 0.22 & $(0.59)$ & 0.72 & \\
\hline EBIT & $\begin{array}{l}\text { Earnings before interest } \\
\text { and taxation to book assets }\end{array}$ & Worldscope & 0.10 & 0.10 & 0.11 & $(0.37)$ & 0.41 & \\
\hline Net Income & Net income to assets & Worldscope & 0.07 & 0.06 & 0.09 & $(0.34)$ & 0.30 & \\
\hline $\begin{array}{l}\text { Cash } \\
\text { Holdings }\end{array}$ & Cash holdings to assets & Worldscope & 0.15 & 0.11 & 0.13 & 0.01 & 0.59 & \\
\hline $\begin{array}{l}\text { Cross- } \\
\text { Listing }\end{array}$ & $\begin{array}{l}1 \text { if the firm is cross-listed } \\
\text { in the USA, either as a } \\
\text { Level 1, Level 2, or Rule } \\
\text { 144a American Depositary } \\
\text { Receipt (ADR), and } 0 \\
\text { otherwise }\end{array}$ & $\begin{array}{l}\text { Bank of } \\
\text { New York, } \\
\text { Citibank, } \\
\text { NYSE, and } \\
\text { Nasdaq. }\end{array}$ & 0.34 & 0.00 & 0.47 & 0.00 & 1.00 & \\
\hline $\begin{array}{l}\text { Industry } \\
\text { Dummies }\end{array}$ & $\begin{array}{l}\text { Industry dummies based } \\
\text { on primary SIC codes }\end{array}$ & $\begin{array}{l}\text { Worldscope } \\
\text { and Author } \\
\text { Calculations }\end{array}$ & & & & & & \\
\hline $\begin{array}{l}\text { Country } \\
\text { Dummies }\end{array}$ & $\begin{array}{l}\text { Country dummy for each } \\
\text { country. Argentina is the } \\
\text { reference country }\end{array}$ & $\begin{array}{l}\text { Author } \\
\text { Calculations }\end{array}$ & & & & & & $\begin{array}{r}\text { Variable description } \\
\text { and summary } \\
\text { statistics }\end{array}$ \\
\hline
\end{tabular}




\section{MF}

41,7

\begin{tabular}{|c|c|c|c|c|c|c|c|}
\hline \multirow[b]{2}{*}{690} & & \multicolumn{3}{|c|}{ Dividend payout } & \multicolumn{3}{|c|}{$\mathrm{RE} / \mathrm{TA}$} \\
\hline & & $\begin{array}{c}\text { Mature } \\
\text { firms }\end{array}$ & $\begin{array}{c}\text { Immature } \\
\text { firms }\end{array}$ & Difference & $\begin{array}{l}\text { mature } \\
\text { firms }\end{array}$ & $\begin{array}{l}\text { Immature } \\
\text { firms }\end{array}$ & Difference \\
\hline & $\begin{array}{l}\text { Corporate } \\
\text { governance }\end{array}$ & 60.56 & 56.71 & $* * *$ & 58.63 & 58.28 & \\
\hline & Tobin's $q$ & 2.17 & 1.54 & $* * *$ & 1.99 & 1.51 & $* * *$ \\
\hline & Free cash flow & 0.10 & $(0.03)$ & $* * *$ & 0.11 & $(0.05)$ & $* * *$ \\
\hline & Dividend payout & 0.059 & 0.009 & $* * *$ & 0.045 & 0.022 & $* * *$ \\
\hline & RE/TA & & & & 0.314 & $(0.023)$ & $* * *$ \\
\hline & Leverage & 0.42 & 0.53 & $* * *$ & 0.41 & 0.54 & $* * *$ \\
\hline & Size & 5.98 & 6.16 & $* * *$ & 6.05 & 6.19 & ** \\
\hline & Growth & 0.067 & 0.059 & $* * *$ & 0.08 & 0.02 & $* * *$ \\
\hline & EBIT & 0.15 & 0.06 & $* * *$ & 0.13 & 0.06 & $* * *$ \\
\hline & Net income & 0.10 & 0.03 & $* * *$ & 0.10 & 0.03 & $* * *$ \\
\hline & Cash holdings & 0.17 & 0.12 & $* * *$ & 0.18 & 0.12 & $* * *$ \\
\hline
\end{tabular}

Table AII.

Comparison of mature and immature firms

Notes: This table compares the average "mature" to "immature" firm. Maturity is determined using either dividend payout (industry-adjusted) or retained equity to total assets (RE/TA). All variables are defined in Appendix 1. "> Median" and " $\leqslant$ Median" refer to above and below-median. The column "difference" refers to the difference between "mature" and "immature" firms, while *******difference in mean values across each group (two-sided t-test) is significant at the 10, 5, and 1 per cent, respectively 
Dividend payout Retained equity to total assets

Above median Below median

Full sample industry payout industry payout Above median Below median

\begin{tabular}{|c|c|c|c|c|c|}
\hline $\begin{array}{l}\text { Corporate } \\
\text { governance }\end{array}$ & $\begin{array}{l}0.015 \\
(1.93)^{*}\end{array}$ & $\begin{array}{l}0.012 \\
(1.05)\end{array}$ & $\begin{array}{l}0.017 \\
(1.77)^{*}\end{array}$ & $\begin{array}{l}0.012 \\
(1.29)\end{array}$ & $\begin{array}{l}0.021 \\
(2.46)^{* * *}\end{array}$ \\
\hline Industry dummies & Included & Included & Included & Included & Included \\
\hline Country dummies & Included & Included & Included & Included & Included \\
\hline Time dummy & Included & Included & Included & Included & Included \\
\hline Controls & Included & Included & Included & Included & Included \\
\hline No. observations & 450 & 221 & 229 & 192 & 212 \\
\hline$R^{2}$ & 0.524 & 0.594 & 0.500 & 0.625 & 0.456 \\
\hline
\end{tabular}

Notes: This table reports coefficient estimates from the second stage equation from a two-stage least squares analysis. We instrument for (firm-level) corporate governance using the yearly industry country specific median values of governance. The instrument is included in the first, but not the second-stage (reported below) regressions. The sample period is for the years 2001 and 2002. Separate regressions are estimated for the full sample of firms, and by level of retained equity to total asset and dividend payout, respectively. The dependent variable is Tobin's $q$. Tobin's $q$ is calculated as the book value of debt plus market capitalization divided by the book value of assets. Corporate governance measures are from CLSA, and are calculated as an equally weighted average of discipline, transparency, independence, accountability, responsibility, fairness, and social responsibility. Firm level control variables, defined in the main text, are included (in both first and second-stage regressions), but not reported. All firm-level data are sourced from Worldscope and information on firms cross-listing in the USA from Bank of New York-Mellon (www.adrbnymellon.com), and cross-referenced with data from Citibank (wwss.citissb.com/adr) and JP Morgan (www.adr.com), the New York Stock Exchange (www.nyse.com), and the NASDAQ (www.nasdaq.com). A full set of industry, country, and time dummies are included where indicated but not reported. *******Significant at the 10,5 , and 1 per cent levels, respectively

Table AIII.

Second-stage two-stage least squares estimates

\section{Corresponding author}

Dr Thomas O'Connor can be contacted at: thomas.g.oconnor@nuim.ie

For instructions on how to order reprints of this article, please visit our website: 